\title{
School Leadership and Teacher Professionalism in Character Learning
}

\author{
Muhammad Alex ${ }^{1 *)}$, Nur Ahyani², Dessy Wardiah ${ }^{2}$ \\ ${ }^{1}$ SD Negeri Tanjung Mas, South of Sumatera, Indonesia \\ ${ }^{2}$ Universitas PGRI Palembang, Indonesia \\ *Corresponding author. Email: malexspd4@gmail.com
}

\begin{abstract}
The leadership of the Principal and Teacher Professionals plays an important role in character learning in schools. This research was conducted with the aim of describing the roles of school principals and teachers in managing character learning at SD Negeri Tanjung Mas. Qualitative descriptive is the method used. With data collection techniques including data collection, observation, interviews, and documentation. The respondents used to be the principal, teachers and students. The findings revealed that the principal of SD Negeri Tanjung Mas exercised successful leadership by performing his positions and functions as educators, managers, administrators, subordinates, representatives, informants, and motivators. Teachers manage learning in the learning process by incorporating character education, selecting the appropriate approach based on the material presented, and selecting learning media that helps students understand the material presented. As well as taking a personal approach for students who have learning difficulties in order to increase interest in learning.
\end{abstract}

Keywords: Character Learning, Principal Leadership, Professional Teachers, Leadership

\section{INTRODUCTION}

Character education in schools would influence each student's personal conduct, decision-making, and character in accordance with the prevailing teachings. In this situation, religious-based character education would obviously be very important to provide for students. Of course, every school must abide by the rules established by the government. One of the rules developed is the use of character values in student learning.

In today's digital era, the government faces a number of challenges in improving the quality of education. The key reason for the government's constant focus on improving the quality of educational staff is the disparity in the quality of teachers in schools. This is sought because the success of the teaching and learning process, which is a synergy of the educational components, is highly dependent on the success of the standard of learning, both curriculums, education personnel, infrastructure, management systems, natural environmental factors and social environment, with students as subjects. The teaching and learning process as a system is influenced by various factors. One of them is a teacher who is the main implementer of education in the field. The quality of teachers, both academic and non-academic, also affects the quality of learning.
Learning is a process of channeling information or messages from educators to students that are planned, designed, implemented, and evaluated systematically at school and outside of school where there will be interactions between the two. Learning is an effort made by a person (teacher) to teach students who learn. Informal education (schools), learning is a task that is borne by the teacher, because teachers are professionals who are prepared for it. Learning is seen as a system, so learning consists of organized components, learning goals, learning tools, learning techniques and procedures, media or teaching aids, class organization, learning assessment, and follow-up are all examples of learning objectives. Learning, on the other hand, is regarded as a process, namely learning as a series of activities designed to help students learn. The procedure begins with the planning of the curriculum and the preparation of the instructional materials, and the supporting tools in the form of media and evaluate.

One of the most important aspects of academic success is the learning process. There is a process of transforming knowledge and values during the learning process. As the learning process occurs, there is contact between the instructor and the students, which allows the teacher to understand the qualities and potential of the students. Similarly, through learning, students have the ability to grow their potential so that it can be maximized. As a result, schooling is no longer a catalyst, but rather an attempt to improve its potential. 
There are four central issues that become educational problems, namely: the relevance of education, educational equity, educational effectiveness, and quality of education. Many parties are involved in an attempt to improve the quality of learning, especially the quality of secondary education, which is one of the educational problems. The skill of teachers from a variety of backgrounds and experiences is one factor that contributes to the improvement of secondary education quality. The duties of the teacher in the classroom include two main things, namely teaching activities and managerial activities.

Efforts to enhance the quality of learning include the principal's skilled leadership role, the role of the teacher in its implementation. With this effort, it is hoped that there will be an increase in the quality of national education. Quality learning management will not be realized if it is not supported by quality learning process support factors. Quality learning management requires trained and skilled staff such as administrators, instructors, psychologists, and administrators to back it up. This is also assisted by academic resources and amenities, as well as facilities, media, and adequate learning opportunities, both in terms of quality and quantity, as well as adequate prices, effective regulation, and a welcoming atmosphere [1]

The government always proclaims educational institutions, especially schools in improving the quality of education and managing learning. Based on the results of observations made on 20 July 2020 - 15 August 2020 at SD Negeri Tanjung Mas, it shows that: 1) There are still teachers who teach not according to their field of study; 2) Teachers only carry out their profession but have not carried out their duties professionally; 3) In the implementation of learning, some teachers still dominantly use conventional methods; 4) In an attempt to enhance management and learning efficiency, the principal's function has not been optimal.

Based on the explanation above, it is deemed necessary to carry out further research. Therefore, researchers are interested in conducting research related to the problems described above with the title "Principal Leadership and Teacher Professionalism in Character Learning". The aim of this research is to identify the principal's and teaching profession's leadership roles in managing characterized learning at SD Negeri Tanjung Mas.

Leadership is a process that affects group activities that are organized to achieve common goals [2], [3]. It very much needs a leader who has the ability to influence others, because a leader has the authority to direct the performance of his members so that they can achieve the goals to be achieved. [4] states that leadership is an activity to influence the behavior of others or the art of influencing human behavior, both individually or in groups.
Influencing activities will certainly occur if the leader is assigned according to his role. The function of the principal is being able to apply management functions to the management of the school he leads. Among its functions are planning, organizing, directing, coordinating, monitoring, educating, managers, leaders, motivators, and staff [5]. From its function, it can be said that the principal in addition to his role as a formal official who has the authority to make decisions and give instructions or orders, the principal also acts as a staff.

The function of the principal as a leader, namely the principal should be able to apply management functions to the management of the school he leads. Among its functions are Planning; Organization; Coordination; Supervision; Principal as Manager; Principal as Leader; Principal as Motivator; Principal as Staff. [5]. When the principal carries out his function and role, so does the teacher. The teacher has a very important role in learning. Students need the role of a teacher to assist them in the process of self-development and optimize the talents and abilities of students.

The teacher's role in learning, specifically, the teacher's role in learning as an educator, teacher, mentor, trainer, advisor, innovator, model and role model, person, researcher, creativity booster, vision generator, routine worker, camp shifting, storyteller, actor, emancipator, evaluator, preservative [6]. In the teaching and learning process, the teacher's position is visible. The teaching and learning process is a sequence of acts by teachers and students that take place in educational circumstances to achieve clear goals [7]. A learning process is necessary to achieve the goal.

Learning is the relationship between students, instructors, and learning tools in an educational environment that encourages for the acquisition of knowledge and skills, mastery of skills, and the development of thoughts and behaviours in students [8]. According to Rukmana and Suryana [9] Learning is a process of seeing and experiencing, observing, and understanding something that is learned to obtain a determined result, through coaching, giving explanations, and encouraging.

Learning can be described as a process of interaction between students, educators, and learning resources in a learning setting. Learning management is closely related to class management, which is the center / place for the teaching and learning process. It can be said that the teacher's role in learning, namely, the teacher as an educator, teacher, mentor, trainer, advisor, innovator, model and role model, person, researcher, creativity booster, vision generator, routine worker, camp shifting, storyteller, actor, emancipators, evaluators, preservatives [10].

Teachers are trained educators whose primary duty is to inform, teach, guide, direct, train, assess, and evaluate students in the formal education pathway in early childhood education, basic education, and 
secondary education [11]. Teachers are people who deliberately influence others to achieve education [12]. Originally the word teacher referred to someone who gave knowledge, skills, or experiences to others. This process is commonly known as learning. Learning is described as the process by which an organism's behavior changes as a result of experience. Learning is basically an operation that anticipates behavioral changes in the learner. From the concept of learning comes the term learning. Which can be viewed as learning in the sense of attempting to teach students [13]. Learning is fundamentally a process of interaction between educators and students, between children and learning opportunities, and between children and educators [14].

Learning is the relationship between students, instructors, and learning tools in a learning environment that allows for the acquisition of knowledge and skills, mastery of skills, and the development of attitudes and beliefs in students [15]. According to [9] Learning is a process of seeing and experiencing, observing, and understanding something that is learned to obtain a determined result, through coaching, giving explanations, and encouraging.

Learning, according to the above description, is a process of interaction between students, educators, and learning tools in a learning environment. Learning management is inextricably connected to class management, which is the focal point of the teaching and learning process. The teaching and learning process in the classroom entails all of the elements in the school. However, the following will be involved directly: Teachers as educators, students as educated, tools / media used, situations in the classroom environment, the school itself. In managing learning, the teacher takes steps for learning activities, namely: 1) Learning planning; 2) Learning implementation; 3) Learning assessment.

\section{METHODS}

This research made use of qualitative analysis methods. This is a qualitative descriptive analysis in which data is obtained by using words and pictures rather than numbers [16]. This study will explain or classify the facts and characteristics of a specific population or object in a systematic, accurate, and reliable manner. This relates to the Principal's and Teachers' leadership positions in learning management as an attempt to enhance the quality of learning at SD Negeri Tanjung Mas.

The principal and teachers of SD Negeri Tanjung Mas were the subjects of this report. Researchers used observation, interviews, and reporting techniques to collect data. The researcher validated the data after analyzing it according to Sugiyono's theory [17]. To obtain relevant data, the researcher validates the research data by extending findings, observing persistence, and triangulating data.

\section{RESULTS AND DISCUSSION}

The general leadership of the SD Negeri Tanjung Mas principal is as follows:

\section{1) Principal as Educator}

In teaching and learning activities, the Principal of SD Negeri Tanjung Mas shows high commitment and focus on curriculum development and teaching and learning activities. In addition, it also pays attention to the level of competence of the teacher, as well as trying to facilitate and encourage teachers to continually improve their competence, so that teaching and learning activities can run effectively and efficiently.

\section{2) Principal as Manager}

The principal of SD Negeri Tanjung Mas is responsible for developing long-term, medium-term, and short-term school work programs in collaboration with teachers, boards, administrators, and local education and community leaders. The principal manages the teaching staff by carrying out maintenance and professional development programs for teachers. $\mathrm{He}$ facilitates and provides ample opportunities for teachers to be able to carry out professional development activities through various educational and training activities. This activity is carried out at school and outside of school.

\section{3) Principal as Administrator}

Actualization The principal, in his capacity as administrator, has a close association with various administrative management activities that are recorded, compiling and documenting all school programs. The principal of SD Negeri Tanjung Mas in carrying out its function as administrator. Apart from that, it also works with student administration, personnel administration, teaching program administration, financial administration, community participation administration, equipment / goods administration. He also requires teachers to make learning, student, and class administration as well as regularly checking teacher administration. So that in general the teacher administration is orderly and good.

\section{4) Principal as Supervisor}

The principal as a supervisor must embody the ability to formulate, and implement educational supervision programs, and take advantage of the results. To assess the degree to which the teacher is capable of carrying out learning, the principal can perform periodic supervision activities, which can be accomplished by class visits to directly observe the learning process, specifically in the selection and use of methods, the media used, and student participation in the learning process. Implementation of the function as a supervisor the principal supervises. In carrying out supervision, he developed a program and schedule of supervision properly, and used various supervision instruments. In 
addition, he also followed up on the findings of supervision and reported the results of supervision to stakeholders for evaluation and further coaching.

\section{5) Principal as Leader}

The principal of SD Negeri Tanjung Mas in carrying out his function as a leader. Able to move all components of the school, including collaborating with alumni. It is proven by the establishment of this relationship that the alumni have provided a lot of assistance in the form of funds and materials, so that schools are able to provide adequate educational infrastructure.

\section{6) Principal as Innovator}

The principal in order to carry out his role and as an innovator, the principal must have the right approach to forge a harmonious relationship with the environment, search for new ideas, incorporate every operation, set a good example for all instructional staff in the school, and create creative learning models. In this case the Principal of SD Negeri Tanjung Mas in carrying out its function as an innovator is very good, the principal always encourages teachers to be innovative, able to utilize existing media in the environment to support and improve the quality of learning and student interest.

\section{7) Principal as Motivator}

As a motivator, the principal "must have the right approach to inspire education staff in carrying out different tasks and functions. This motivation can be cultivated through setting the physical environment, setting the work atmosphere, discipline, encouragement, appreciation effectively, and providing various resources through the development of learning resource centers.

Based on the results of interviews with all educational components at SD Negeri Tanjung Mas, it was found that the principal could carry out his duties and functions very well. Based on this, the authors conclude that a principal's role as a leader, whether as an educator, manager, administrator, boss, leader, innovator, or motivator, should run smoothly and successfully. This is complemented by determination, enthusiasm, self-competence / ability, as well as the courage to use Strength, face obstacles, take advantage of opportunities, and face challenges. Besides, it must have the ability to build relationships with stakeholders.

The Role of Teacher Professionalism in Learning Management at SD Negeri Tanjung Mas:

\section{Teacher's Efforts in Managing the Material}

Based on the findings in the teaching learning process in processing the material according to the RPP and syllabus. In addition, the teacher has also mastered the material. This can be seen at the time he taught in class. The teacher does not open the lesson and the teacher loudly delivers the material. This can be seen when researchers make observations, teachers process the material by making lesson plans according to learning. When delivering material, the teacher coherently delivers the material to students, so that students understand what the teacher says. In addition, the teacher, when students ask questions, the teacher easily answers them. This makes students pay more attention to the teacher when explaining the material presented. Teachers must master the lesson material as well as possible, so that they can plan lessons well, think about variations in methods, how to solve problems and limit materials, guide students towards the expected goals, without losing confidence in themselves.

\section{The teacher's efforts in choosing a method}

The approach is a method for putting learning strategies into action in order to maximize learning goals. In question practice the teacher invites students to do the game method, namely the teacher directly invites students to sing after that, students are appointed to answer and explain the practice questions given.From the results of the research, it can be said that in increasing the interest in learning of SD Negeri Tanjung Mas students in subjects, the method selected must be in accordance with the material presented. The teacher uses methods to increase interest in learning, namely by the method of lectures, questions and answers, group discussions, story methods and games. When the teacher uses the game method the students are very conducive to following it. Although there are some students who are still unclear about the material presented. At least students become interested in taking part in learning, with students starting to follow the learning process slowly students will like the lesson.

\section{The efforts of the teacher in using learning media/simple media}

The use of media is a way to motivate, foster interest and communicate with students to be more effective. Using media in learning allows improving learning outcomes individually and personally according to their speed. Teachers must have basic skills in selecting media skills to increase student interest in learning. When the researcher made observations, the media used by the Tanjung Mas Public Elementary School teachers were using the blackboard media available in each class. The instructor writes the content that was provided at the time on the blackboard, which provides students with good memories. The instructor employs basic media in addition to blackboard media. The teacher hopes that by using simple media, students can pay more attention to the teacher while he or she is presenting the content. In selecting media, the teacher can take advantage of existing media or the teacher can design media for learning purposes such as making photo media, films and so on. Choosing media in learning are not easy. If a lesson is to be achieved well, 
the teacher must understand and know the various types and characteristics of the media. Media is used not for decoration in a learning process, but with the media, teachers can increase interest in learning.

\section{The teacher's efforts to increase interest in learning}

It is important to promote interest in learning during the teaching and learning engagement phase. The teacher must have a way so that students are not lazy in participating in learning. In learning, the teacher must be able to foster student interest in learning, and students will not be bored with learning. Teachers must create effective learning to increase student interest in learning. When the researcher observes the teacher's efforts in increasing student interest in learning is by providing opportunities to ask questions and giving opportunities to students to convey the material being studied at that time. In addition, teachers communicate well with students. The teacher must create effective teaching and foster student interest in learning, the efforts that the teacher must make are the teacher must use many methods of learning, motivation in student development, in teaching and learning interactions the teacher must provide many opportunities to ask questions, to be able to investigate for themselves.

The researcher concludes that the efforts made by Tanjung Mas SD Teachers are to give students opportunities to ask questions and interact effectively with one another in order to increase student interest in learning. By communicating with students well, it will provide opportunities for teachers to approach students who have learning difficulties. In addition, the Principal of SD Negeri Tanjung Mas will hold extracurricular activities. According to researchers, the teacher's effort in increasing interest in learning is by providing opportunities for students to ask questions. Then invite students to study outside the classroom, approaching students who have difficulty in learning. Furthermore, it provides motivation in learning and good communication with students. This good communication is done so that interaction occurs and students are brave in expressing ideas and responding to material problems presented.

\section{CONCLUSION}

In carrying out his leadership, the principal of SD Negeri Tanjung Mas has successfully carried out his roles and functions as an Educator, Manager, Administrator, Supervisor, Mentor, Innovator, and Motivator. The principal of SD Negeri Tanjung Mas has the determination, enthusiasm, competence / ability, as well as the courage to use Strength, face Weaknesses, take advantage of Opportunities, and face Threats, besides that he also has the ability to build relationships with existing stakeholders.

Apart from the principal who has played his role as a leader in managing learning, teacher professionalism is also an important factor in managing learning to achieve quality education. The efforts made by the teacher in managing character learning in the classroom, namely: managing the subject matter to be taught; selecting the appropriate approach based on the content being taught in order to increase students' interest in learning; selection of learning media so that students easily understand the material; increase student interest in learning by approaching students who have difficulty in learning.

\section{ACKNOWLEDGMENT}

Our deepest gratitude goes to Teachers in SD Negeri Tanjung Mas, Chancellor of Palembang PGRI University, Director of the Postgraduate Program of PGRI Palembang University and the Education Management Study Program of PGRI Palembang University, who have supported us in doing this extraordinary thing. This project is funded independently. We also want to thank our Education Management friends who helped us a lot in a short time frame to complete this project.

\section{REFERENCES}

[1] Sukmadinata, N. S. (2009). Landasan Psikologi dan Proses Pendidikan [Basis of Psychology and Educational Process]. Bandung: PT Remaja Rosdakarya.

[2] Indrafachrudi, S. \& Tahalele J. F. (2006). Mengatur Bagaimana Memimpin Sekolah yang Efektif [Organizing How to Lead Effective Schools]. Jakarta: Ghalia Indonesia.

[3] Danim, S. (2002). Menjadi Peneliti Kualitatif [Become a Qualitative Researcher]. Bandung: Pustaka Setia.

[4] Permadi, K. (1996). Pemimpin dan Kepemimpinan Dalam Manajemen [Leaders and Leadership in Management]. Jakarta: Rineka Cipta.

[5] Hasan, A. (2014). Marketing dan Kasus-Kasus Pilihan [Marketing and Choice Cases]. Jakarta: CAPS.

[6] Mulyasa, E. (2007). Standar Kompetensi dan Sertifikasi Guru [Competency Standards and Teacher Certification]. Bandung: PT. Remaja. Rosdakarya.

[7] Usman, M. U. (2006). Menjadi Guru Profesional [Become a Professional Teacher]. Bandung: Remaja Rosdakarya.

[8] Sagala, S. (2010). Konsep dan Makna Pembelajaran [Concept and Meaning of Learning]. Bandung: Alfabeta.

[9] Rukmana, A., \& Suryana, S. (2006). Pengelolaan Kelas [Class management]. Bandung: UPI PRESS. 
[10] Mulyasa, E. (2007). Standar Kompetensi dan Sertifikasi Guru [Competency Standards and Teacher Certification]. Bandung: PT. Remaja. Rosdakarya.

[11] Arikunto, S. S., \& Supardi. (2014). Penelitian Tindakan Kelas [Classroom action research]. Jakarta. Bumi Aksara.

[12] Muliawan, J. U. (2005). Pendidikan Islam Integratif [Integrative Islamic Education]. Yogyakarta: Pustaka Pelajar.

[13] Pirdata, M. (2011). Manajemen Pendidikan Indonesia [Indonesian Education Management] Cet. I. Jakarta: PT Rineka Cipta.

[14] Sagala, S. (2010). Konsep dan Makna Pembelajaran [Concept and Meaning of Learning]. Bandung: Alfabeta.

[15] Rukmana, A dan Suryana, S. (2006). Pengelolaan Kelas [Class management]. Bandung: UPI PRESS.

[16] Danim, S. (2002). Menjadi Peneliti Kualitatif [Become a Qualitative Researcher]. Bandung: Pustaka Setia.

[17] Sugiyono. (2019). Metode Penelitian Kuantitatif Kualitatif [Qualitative Quantitative Research Methods]. Bandung: Alfabeta. 